PÉTER KOVÁCS

\title{
ANNAMATIA (BARACS) - A ROMAN AUXILIARY FORT IN PANNONIA
}

\begin{abstract}
Summary: The Roman auxiliary fort of Baracs can be identified with antique Annamatia. The site had not been previously investigated. Excavations were begun in 1999. During the two campaigns, the southwestern corner and the northern gate of the fort were uncovered. This preliminary report offers an overview of the most important results and finds of the excavation. The remains of a 1st century earth-andtimber fort were also unearthed.
\end{abstract}

Key words: auxiliary fort, Baracs, Annamatia, Pannonia.

Antique Annamatia lies on the Eastern Pannonian limes, south of Intercisa (Fig. 1). ${ }^{1}$ It can be identified with the modern village of Baracs (County Fejér). The site had not been previously investigated and very few inscriptions (CIL III, 3326=10302, 3333, 10639-10641, milestones-55 MP of Aquincum, IGRR I 534, AÉp 1977, 644, 1993, 1298, Alba Regia 15, 1976, 205, Nr. 4) and other finds from Baracs have been

\footnotetext{
${ }^{1}$ WOSINSKY, M.: Tolna vármegye az öskortól a honfoglalásig II - History of Tolna county from prehistory to the Conquest period. Budapest 1896, 722, 755-756; GRAF, A.: Übersicht der antiken Geographie von Pannonien. DissPann I.5. Budapest 1936, 107; PWRE IX. Suppl. Stuttgart 1962, 8-11; TIR L-34. Budapest 1968, 28; Der römische Limes in Ungarn. Székesfehérvár 1976, 106-107; VISY, Zs.: Der römische Limes in Ungarn. Budapest 1988, 108-110; VISY, Zs.: A ripa Pannonica Magyarországon - The ripa Pannonica in Hungary. Budapest 2000, 76-77; KovÁCS, P.: Vicus és castellum kapcsolata az alsó-pannoniai limes mentén - Vicus and castellum along the Lower Pannonian limes. Piliscsaba 1999, 42; for the section of the limes road between Intercisa and Annamatia and its watchtowers, cp. FITZ, J.: Örtornyok Intercisa és Annamatia között - Burgi zwischen Intercisa und Annamatia. ArchÉrt 82, 1955, 69-79; VISY, Zs.: Római jelzőtornyok és a limes-út Intercisa térségében - Römische Wachttürme und die Limesstrasse im Raum von Intercisa. ArchÉrt 107, 1980, 166-175; for aerial photos, cp. VISY, ZS.: Pannonische Limesstrecken in Ungarn auf Luftaufnahmen. Antike Welt 1981, 49, Abb. 14; VISY, Zs.: Guide to the excursion on the ripa Pannonica. Excursion guide. 31st International Symposium on Archaeometry 27 April-1 May 1998. Budapest 1998, 81, Fig. 21; for medieval sites in the area, cp. KulCSÁR, M.: Az Árpád-kori templom körüli temetők kialakulásának kérdéséhez (Előzetes beszámoló az 1993-1994. évi baracsi feltárásokról) - Vorbericht über die freilegung des arpadenzeitlichen Gräberfeldes von Baracs (1993-1994). Somogy megyei Múzeumok Közleményei 11, 1995, 227-236; FITZ, J.: Régészeti kutatások Archaeological investigations. Alba Regia 4-5, 1963-64, 175.
} 


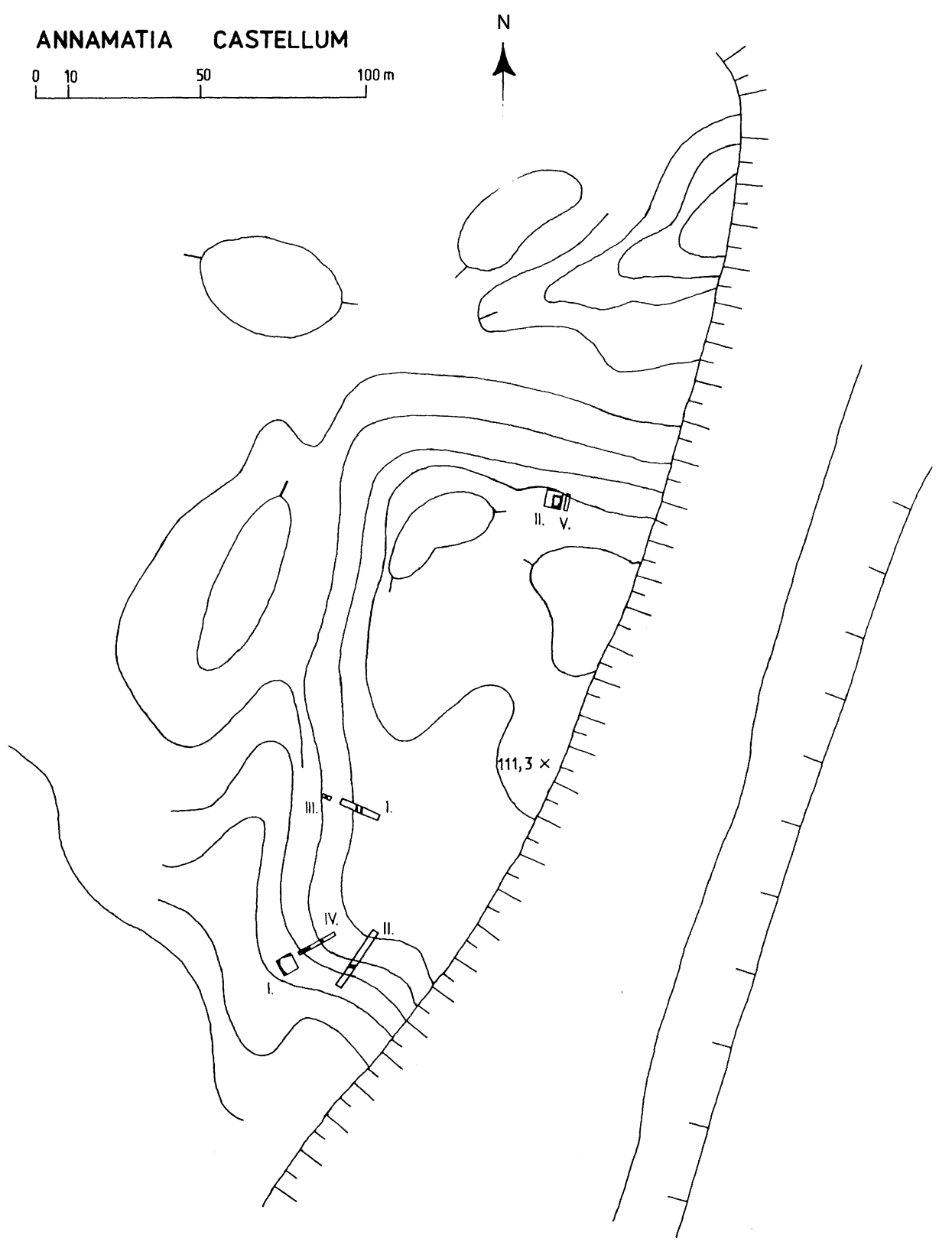

Fig. 1 

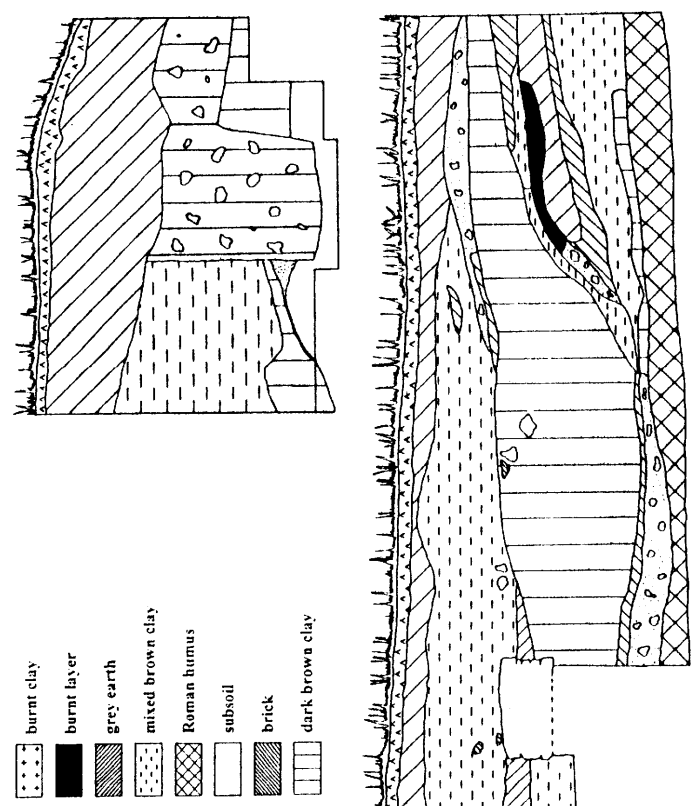

$\because$ $\because \mathbb{Q}$

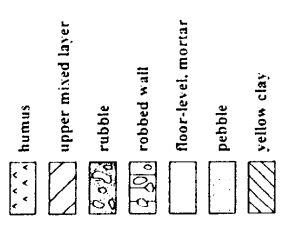
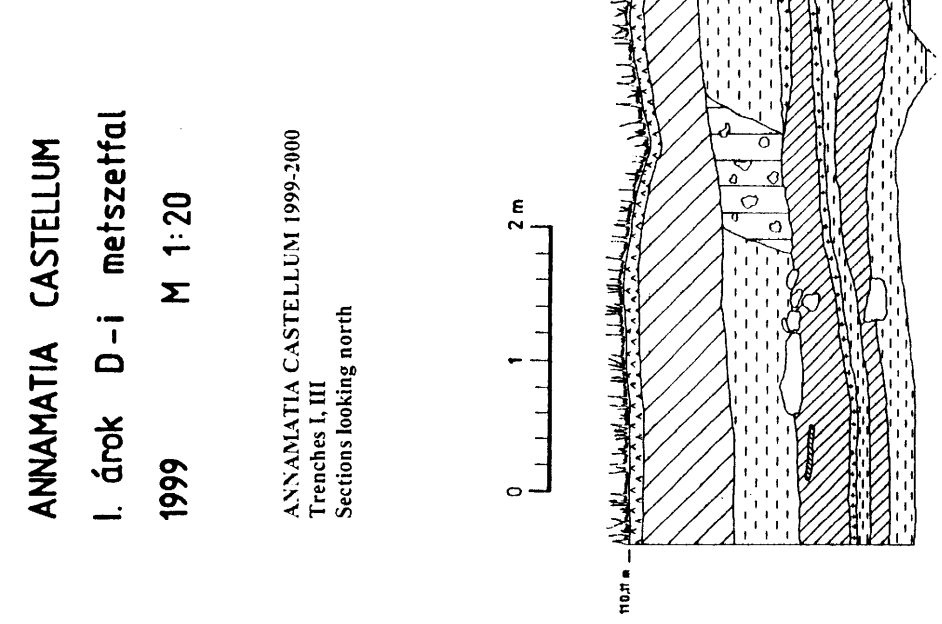
published. ${ }^{2}$ The archaeological investigation of the area was begun in 1999 with the support of the Pázmány Péter Catholic University and the Intercisa Museum. ${ }^{3}$ The antique literary sources only mention the fort (It. Ant. 245, 2, Tab. Peut. Seg. IV, Not. Dig. occ. XXXIII, 95, Geogr. Rav. 220, 2). This fort was one of the least known Pannonian auxiliary forts.

The area of the fort is depicted on 18th-19th century maps. ${ }^{4}$ Marsigli depicted the U-shaped form of the fort, but he identified its site with the modern village of Kisapostag mentioned as Postak, north of Baracs. ${ }^{5}$ The maps of M. Karpe (1775) and J. Rieder (1826) correctly depict the fort called 'Római sáncz' (Roman ramparts).

${ }^{2}$ For coins, cp: Die Fundmünzen der römischen Zeit in Ungarn I. Komitat Fejér. Bonn-Budapest 1990, 26-28; for Samian ware, cp. GABLER, D.: A dunai limes I-II. századi történetének néhány kérdése - Some remarks on the history of the Danubian limes of the first and second century. ArchÉrt 104, 1977, 150, note 64; GABLER, D.: Die Sigillaten von Pfaffenhofen in Pannonien. ActaArchHung 30, 1978, 108, No. 25; GABler, D.- Kellner, H.-J.: Die Bildstempel von Westerndorf II. Helenius und Onniorix. $B V B l$ 58, 1994, 244, T. 33. 3, 34. 5; for Pannonian grey slip ware, cp. MARÓTI, É.: A római kori pecsételt kerámia és a Resatus-kérdés - Römerzeitliche gestempelte keramik und die Resatus-Fragmente. Studia Comitatensia 21, 1991, 365-427, 381, 384, No. 3; for other pottery finds, cp.: BóNIS, K.: A császárkori edénymüvesség termékei Pannoniaban - Die kaiserzeitliche Keramik von Pannonien I. DissPann II. 20. Budapest 1942, 181, T. XXXIII. 9-8; for lamps, cp. IVÁNYI, D.: A pannoniai mécsesek. Tipológiai és kronlógiai áttekintés - Die pannonischen Lampen. Eine typologisch-chronologische Übersicht. DissPann II. 2. Budapest 1935, 130, No. 1384; for glass, cp. BENKÖ, A.: Üvegcorpus - Glass corpus. Régészeti Füzetek II. 1. Budapest 1962, 92, type 4a. 7; for bronze objects, cp. HAMPEL, J., ArchÉrt 22, 1902, 430; GÁsPÁR, D.: Römische Kästchen aus Pannonien. Antaeus 15, 1986, 109, No. 19-21, T. CCIII, CCCI; VISY, Zs.: Basen und Fragmente von Kaiserstatuen in Intercisa. Acta ArchHung 35, 1983, 82, No. 13; KovRIG, I.: A császárkori fibulák fó formái Pannoniában - Die Haupttypen der kaiserzeitlichen Fibeln in Pannonien. DissPann II. 4. Budapest 1937, 80, No. 188, 86, No. 198; TóTH, K.: Római gyürük és fibulák - Ringe und Fibeln im Ungarischen Nationalmuseum. Budapest 1985, 59, Abb. 25. c; for stamped tiles, cp. LöRINCZ, B.: Pannonische Stempelziegel I. Limes-Strecke Annamatia-Ad Statuas. DissArch II. 5. Budapest 1976, 46-51.; for military diplomas, cp. RMD II 113.; Graffitto: Instrumenta Inscripta Latina. Das römische Leben im Spiegel der Kleininschriften. Pécs 1991, 166, No. 288.

${ }^{3}$ The consultants of the excavation were D. Gabler and Zs. Pongrácz. The participants were the students of the Catholic University E. Fácányi, M. Pataky, M. Dági and L. Thúry. I am especially indebted to Prof. István Bóna and Prof. Miklós Maróth for their support. I also wish to thank the local government of Baracs and József Makó (mayor of Baracs) for their help.

${ }^{4}$ Annamatia was not shown on the maps of the 1 st and the 2nd military surveys of Hungary (XIII.26-1783, XXXII-56-1856-186). The section of the 3rd survey shows clearly the ramparts of the fort $(5262 / 1-1882)$.

${ }^{5}$ Marsigli, L. F..: Danubius Pannonico-Mysicus I-II. 1726, 5, Sect. VII; VISY, Zs.: Pannoniai limes-szakaszok légifényképeken - Pannonische Limesabschnitte auf Luftaufnahmen. ArchÉrt 105, 1978, 257. Marsigli described the forts of Intercisa and Annamatia as follows: fortalitiorum reliquiae adhuc visuntur (aa), quorum illud, quod est remotius a Pantalia, Postam nuncupant. The "remotius Postak" can be identifed with Annmatia because Kisapostag and Baracs were administratively separated in 1921 . Kisapostag lies nearer to the fort (north of Annamatia) than Baracs (west of Annamatia) and even in the last century it was disputed whether the area of the fort belongs to Apostag or Baracs (cp. Archaeologiai Közlemények 4, 1864, 47).

${ }^{6}$ Fitz, op. cit. (note 1), 70, 72, Figs 1-2. Inv. No. Nat. Archives A 156. S. Mikoviny's map from around 1740 also mentions a "col. Romana" (identified with Alta Ripa) on the northern outskirts of Dunaföldvár: Mikoviny, S.: Mappa Iconographica comitatuum Pest, Pilis et Solth, cp. also BENEDEFy, L.: Mikoviny S. megyei térképei különös tekintettel az Akadémiai Könyvtár Kézirattárának Mikoviny térképeire - S. Mikoviny's county maps, including the maps in the collection of the Manuscripts Collection of the Library of the Academy of Sciences. Budapest 1976, 155. VISY, op. cit. (note 1), 76, note 517, identified this "col. Romana" with Annamatia which lies approx. $6 \mathrm{~km}$ north. The site can also be identified with the Bronze age hillfort of Baracs lying south of Annamatia which actually lies near Dunaföld- 
The praetoria side of the fort is almost completely missing because the Danube has eroded its eastern part. The site became known in the earlier 19th century when, according to E. Fényes, a Roman house was found at Baracs, together with pottery finds, coins and stamped bricks. ${ }^{7}$ The identification of the site with Annamatia was disputed in the 19th century (cp. CIL III, 429). Mór Wosinszky was the first to correctly identify the fort with Annamatia at the end of the 19th century. ${ }^{8}$ In the 1860 s and 1870s in the area of the fort was planted with vines, and several finds came to light from the area of the fort (including the altar-stones mentioned above, several hundred coins, etc.). ${ }^{9}$ According to F. Rómer's notes, a larger building (measuring by $4 \times 13^{0}$ ) was found in the middle of the fort. Its brick walls were hardly destroyed. It can probably be identified with the headquarters building (principia). L. Höke mentioned that another building with its terrazzo-floor (measured by 3 and $5^{0}$ ) was identified in the southern part of the fort.

The walls of the fort and the inner buildings were systematically dismantled and reused from the later 18th century. It is proven by the fact that Karpe's map did not depict standing walls (rising above the ground level). The neighbouring medieval villages (Baracs and Kisapostag) were destroyed by the Turks in the 16th century and they were only resettled in the 18 th century. ${ }^{10}$ The plough-lands of Baracs were continuously used by the inhabitants of Dunapentele. ${ }^{11}$ In the 18th century Baracs and Kisapostag were in the possession of the Rudnyánszky family. As far as I know, the first major buildings (and resettling) can be dated to the 1760s. There is evidence that in this period a manor house and other houses were built northwest of the fort, exactly as shown on the 18th century maps. This is important in terms of the destruction of the fort because the walls of the southwestern tower were robbed in this period (see below). The stone material of the fort was reused for the construction of several manor houses at Baracs, all built in the 19th century (for example the Derecskei, Kornis and Szluha families, in the vicinity of the fort).

During the excavations in 1999-2000 we uncovered a part of the southwestern angle tower (trench IV, section I) (Fig. 2) and the northern gate (trench V, section II)

vár. The bronze age hillfort was rebuilt as a lunette (earthwork) during the war against the Austrians in 1704 and it is called Bottyán-sánc after General Bottyán: Bronzezeit in Ungarn. Frankfurt am Main 1992, 146-148; BÓNA, I., ArchÉrt 90, 1963, 295; CZIRÁKY, Gy.: Tolnavármegyei Dunaföldvár multja és jelene - Past and present of Dunaföldvár in Tolna county. Dunaföldvár 1910, 76. This earthwork was also thought to be of Roman origin even in the 19th century (e.g. ArchÉrt 2, 1870, 9-10). On the other hand, Mikoviny's map of Fejér county (T 45-T. 6) depicted two separate earthworks called Bottyán-sánc north of Dunaföldvár. The latter one is depicted in the place of Annamatia.

${ }^{7}$ FÉNYES, E.: Magyarország 's a' hozzákapcsolt tartományoknak mostani állapotja I- Hungary and its provinces. Pest $1837,82$.

${ }^{8}$ WOSINSZKY, op. cit. (note 1), 658, 755-756. For an overview of earlier identifications, cp. Cziráky, op. cit. (note 6), 34-37.

${ }_{9}^{9}$ RÓMER, F., Archaeologiai Közlemények 4, 1864, 47-48, 57 and Archaeologiai Közlemények 6, $1866,98,165$, as well as Rómer's diaries (manuscript): XIII, 102-110 (1864), XX, 81-82 (1866), XXXII, 106 (1871); HÖKE, L., ArchÉrt 2, 1870, 8-9, 170, 311-312; TAUSCHER, Gy., ArchÉrt 5, 1872, 102,139

${ }^{10}$ ZÁTORSZKY, M.: Baracs. FMTÉ 13, 1979, 409-439, 410-143; Kisapostag. FMTÉ 20, 1989, 79-81; Pesty Frigyes helységnévtára - Frigyes Pesty's gazetteer. FMTÉ 11, 1977, 177-179.

${ }^{11}$ Dunaújváros története - History of Dunaújváros. Dunaújváros 2000, 112, 123, 127, 129, 135. 
(Fig. 3), as well as a short section of the western and southern fort wall (trenches IIII). A small part of a late Roman building was unearthed in trench I as well. In this paper I shall offer an overview of the results of these excavations. On the basis of our excavations we could reconstruct the size of the entire fort. The full length of the fort is approx. $165 \mathrm{~m}(\mathrm{~N}-\mathrm{S}$ direction). Its surviving $\mathrm{E}-\mathrm{W}$ length is approx. $95 \mathrm{~m}$ in the northern side and $40 \mathrm{~m}$ in the southern side because of the erosion. The auxiliary $v i$ cus lay around the fort (but mainly west of the fort). Buildings with stone foundations could be observed north and south of the fort in the collapsed river bank. ${ }^{12}$ The roughly $5 \mathrm{~m}$ wide $\mathrm{V}$ shaped double ditches of the fort and the remains of the dismantled northern fort wall could also be seen in the river bank. We cut through the rampart and fort wall in the retentura with trenches I (13 x $2 \mathrm{~m})$ (Fig. 4) and III ( $3 \times 1 \mathrm{~m})$. Trench III was opened $3 \mathrm{~m}$ west of trench I. In trench III we found the remains of the completely dismantled $1 \mathrm{~m}$ wide fort wall. Its foundation lay $106.7 \mathrm{~m}$ a.s.l. In the western part of trench I we uncovered the inner earthen rampart of the fort wall that had originally been about $6.5 \mathrm{~m}$ wide. It consisted of brownish and yellowish clayey layers that hardly contained any finds. The overlying strata followed the inclination of the Wehrgang, some of them were burnt. $8.5 \mathrm{~m}$ east of the fort wall we found the $80 \mathrm{~cm}$ wide, north-south wall (wall 1) of an inner building that had probably been robbed by the Romans. Its surviving height is $50 \mathrm{~cm}$, the bottom of its foundation lay $108.45 \mathrm{~m}$ a.s.l. Three rows of stones remained, the stones (and brick fragments among them) of the lower rows were undressed. The burnt clayey floor level belonging to wall 1 was $108.58 \mathrm{~m}$ a.s.1. This floor level could be noted in the whole section of trench I $(5.2 \mathrm{~m}$ long). Wall 1 was pulled down by the Romans and a new one was built $0.9 \mathrm{~m}$ to its east. It was $50 \mathrm{~cm}$ wide, the bottom of its foundation lay 108.65 a.s.l. It survived to a height of $70 \mathrm{~cm}$ (the standing height is $55 \mathrm{~cm}$ ). It had a $15 \mathrm{~cm}$ wide projection footing only in its eastern face. The foundation had only one row of stones. The stones of the two lower rows were undressed and they were set in clay. The burnt clayey floor level belonging to this second wall lay $108.7 \mathrm{~m}$ a.s.l. It reached the wall by the socle. A golden earring, a silver ring and a bronze knee shaped brooch were found it. $2.8 \mathrm{~m}$ east of the wall the floor level was cut through by a $80 \mathrm{~cm}$ wide robber pit. Its bottom lay at a similar depth as that of wall 2, suggesting that a partitioning wall of the inner building had been robbed. This is also confirmed by the fact that larger stones were observed beside it. A $50 \mathrm{~cm}$ thick mixed rubble layer was uncovered east of the walls. It contained dozens of intact imbrices, tegulae and fragments of the roof. In this layer a gilded silver crossbow brooch and an aes of Constantius II were found. The stamped tiles belong to the legio II adiutrix-, Exercitus Pannoniae Inferioris- and cohors VII Breucorum types. On the basis of the finds, wall 1 can be dated to the 3rd century, while wall 2 can be dated to the earlier 4th century. Two postholes were found in wall 2 (diam: $35 \mathrm{~cm}$, depth: $50 \mathrm{~cm}$ ) and $2.5 \mathrm{~m}$ to its east (diam: 40, depth: $30 \mathrm{~cm}$ ). They probably belonged to a late Roman timber building that can be dated to after the mid-4th century on the basis of the coins of Constantius II. The clayey layer above the earthen rampart containing charcoal can also be dated to this period. We

${ }^{12}$ ArchÉrt 117, 1990, 123; KovÁcs, op. cit. (note 1), 42. 

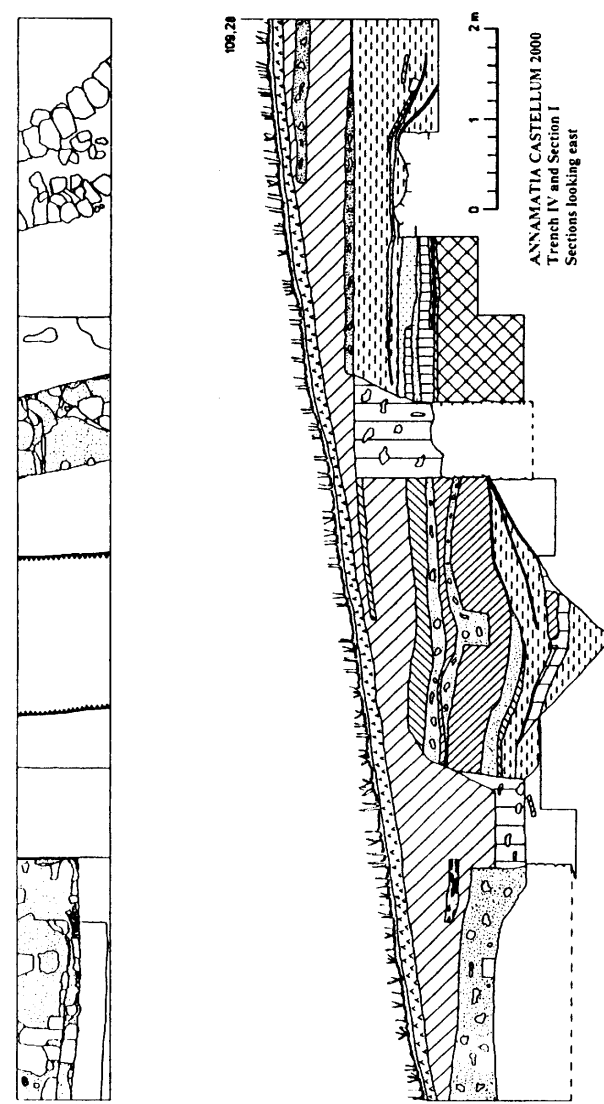

象
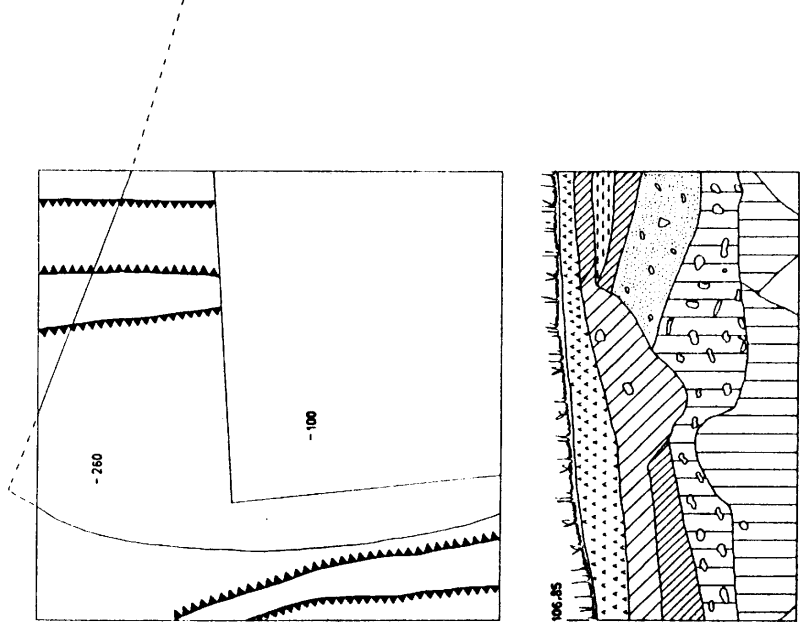

Acta Ant. Hung. 41, 2001 

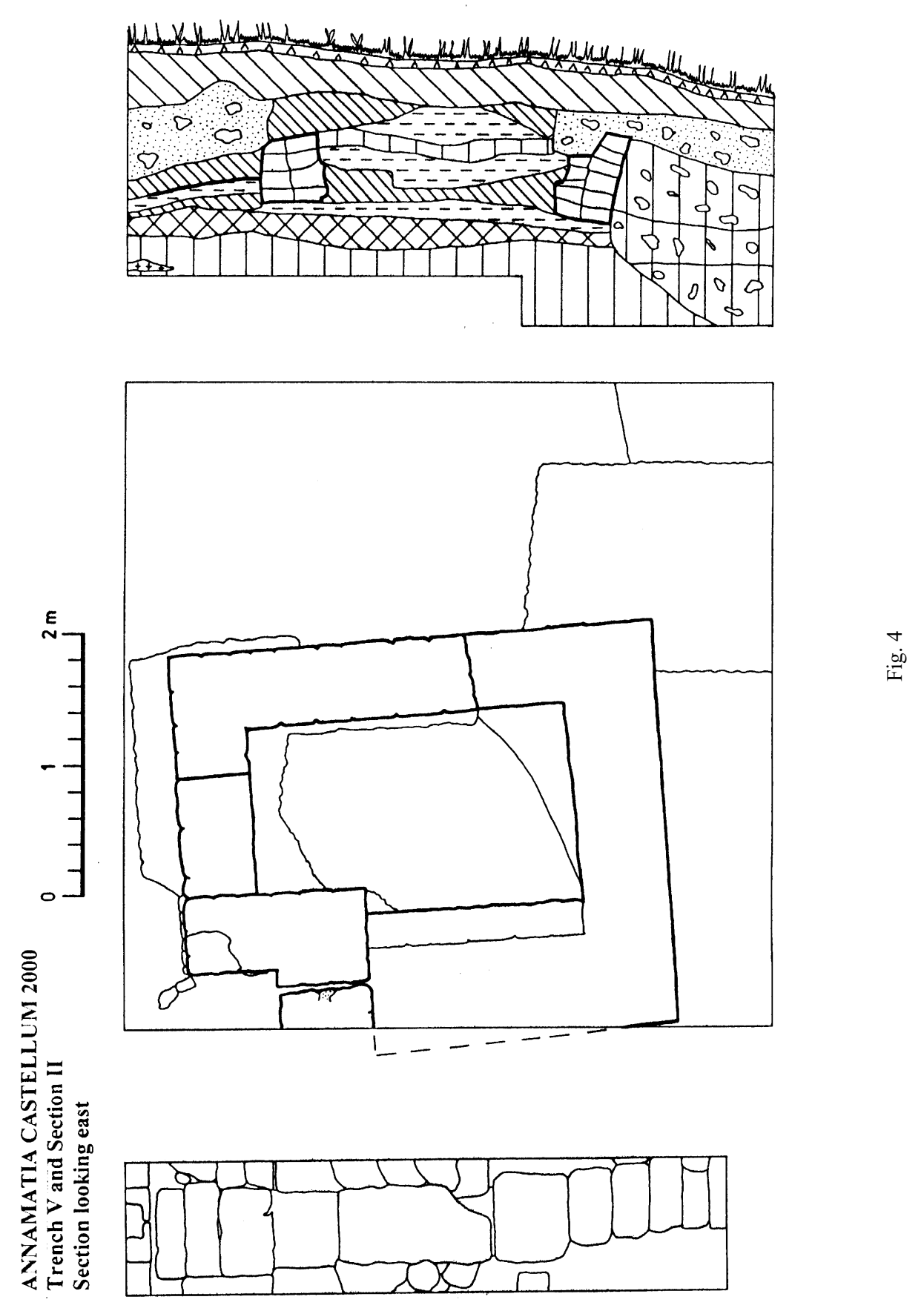

Acta Ant. Hung. 41, 2001 
did not find any late Roman building added to the fort wall or stamped bricks from the Valentinian period.

Below floor level 2, at a depth of $1.8 \mathrm{~m}$, we uncovered the earlier structures of the stone period. On the basis of the mud bricks and larger terrazzo fragments the 1st period inner building had mud walls with a stone foundation and terrazzo floor. In the eastern end of trench III we uncovered a section of the ditch of the earth-timber period fort that followed the direction of the wall. An $50 \mathrm{~cm}$ wide small pit east of the wall also belongs to this period.

In trench II $(20 \times 2 \mathrm{~m})$ we cut through the southern fort wall and the rampart. The fort wall was $1 \mathrm{~m}$ wide, its surviving height is $60-90 \mathrm{~cm}$ (the height of the ascending wall is $30 \mathrm{~cm}$ ). The bottom of its foundation lay $106.63 \mathrm{~m}$ a.s.l. The lower two rows of stones were undressed and the third one was set in mortar. The ascending wall consisted of larger ashlars and bricks set in mortar. The outer face of the wall is almost completely covered by mortar. North of this wall, under the rampart, we found the building level of the fort wall. The brown earthen rampart was $8 \mathrm{~m}$ wide here and it contained very few finds. Only a 1st century lamp fragment is noteworthy among the finds. It was partly removed in the late Roman period and limy and clayey road levels were found on it. An oven was uncovered $4.8 \mathrm{~m}$ north the fort. Its diameter was $1.2 \mathrm{~m}$. Its firing plate (108.32 m a.s.1.) consisted of Roman pottery and brick fragments. Its surviving height is $25 \mathrm{~cm}$. Around the oven yellow mudbricks and stones were observed. Its pit lay west of the trench. It was levelled in Roman times and the levelling layers followed the inclination of the rampart. North of the Wehrgang we also uncovered a $3.3 \mathrm{~m}$ wide section of the via sagularis. The road was cobbled and had been renewed once. It had kerb stones. In the northwestern corner of the trench a $40 \mathrm{~cm}$ wide drain was found (108.39 m a.s.1.) that followed the line of the fort wall. Its stones were set in clay. On the basis of the stratigraphy it belonged to the 2 nd period road. Above the channel a $40 \mathrm{~cm}$ thick mixed fill was observed which contained several Samian ware fragments and a human skull. Above it a burnt clayey level and a gravelly level were unearthed. They can be dated to the late Roman period. No late Roman inner buildings were identified in this trench, the above mentioned features were most likely only road levels of this period. The distance between the fort wall and the ditch was $3 \mathrm{~m}$. In this trench we did not find any features that could be associated with the earth-timber period and we did not investigate the whole ditch either because of its depth $(2 \mathrm{~m})$.

The southwestern angle tower was unearthed in trench IV $(12 \times 1 \mathrm{~m})$ and section I $(5 \times 5 \mathrm{~m})$. We cut through the fort wall and the towers in trench IV and the fan shaped tower was unearthed by section I. In trench IV we uncovered the 0.9 m wide posterior wall of the 1st period trapezoid angle tower. Its surviving height is $40-110 \mathrm{~cm}$. The bottom of its foundation lay $106.49 \mathrm{~m}$ a.s.l. Three rows of stone of the ascending wall were found. The stones were set in mortar. The foundation had three rows of stones set in clay. A North Italian thin-walled cup fragment was found in the humus soil beside the fort wall. The 1st ditch of the earth-timber period was uncovered $0.7 \mathrm{~m}$ south of the fort wall. It was $2.2 \mathrm{~m}$ wide, $1 \mathrm{~m}$ deep. A North-Italian Samian ware fragment was found in its fill. Its direction followed the line of the fort wall. A demo- 
lition layer of a totally robbed $1 \mathrm{~m}$ wide curving wall was observed $3.3 \mathrm{~m}$ south of the fort wall. The bottom of its foundation lay $106.57 \mathrm{~m}$ a.s.l. The robbed wall can be identified with a section of the fort wall because of its similar width and foundation depth. Between the fort wall and the wall of the tower we observed the clayey and the mortar floor levels of the tower that had sunk owing to the earth-timber period ditch below it. The building levels of the fort wall and the fan shaped tower were observed below and above the floor. A $3.5 \mathrm{~m}$ wide road level (via sagularis) was unearthed north of the posterior wall. The first period road was indicated by a yellow clayey level. It followed a gravelly level that was renewed twice. Two parallel rows of stone set in clay were found (at a distance of $50 \mathrm{~cm}$ from each other) $1.8 \mathrm{~m}$ north of the fort wall. They were $30 \mathrm{~cm}$ wide. It was most likely a section of the drain observed in trench II. It was apparently unused in the latter two periods of the road because these levels extended over the drain. A Pannonian grey slip ware fragment was found among the stones of the drain.

The longitudinal wall of the fan shaped tower was added to the fort wall. This would imply that this auxiliary fort did not have any semi-circular angle towers. The $1.5 \mathrm{~m}$ wide wall of the fan shaped tower had a $20 \mathrm{~cm}$ wide projecting footing, the bottom of its foundation lay $105.7 \mathrm{~m}$ a.s.l. Its surviving height is $80-90 \mathrm{~cm}$, and only a single row of stones of the standing wall survived. The stones (of the foundation as well) were set in mortar. Beside the foundation the wider, parallel foundation ditch filled with stones and mortar was also observed. The outer curve of the tower was unearthed by section I, $2 \mathrm{~m}$ south of trench IV. The walls of the tower were totally robbed here. In the demolition layer of the curve a 2 Kreuzer coin of Maria Theresa (empress of Austria and queen of Hungary) was found (1762). This coin dates exactly the time of the robbing. The floor levels of the tower remained intact in the southwestern part of the section. Three yellow clayey floor levels were found. The foundation of the outer curve of the tower lay $13 \mathrm{~cm}$ deeper than the longitudinal walls. The base of their foundations lay at $105.33 \mathrm{~m}$ and $105.46 \mathrm{~m}$ a.s.l. Three ditches were uncovered below the foundation of the walls. The first one (nearer the fort wall) was only $80 \mathrm{~cm}$ wide. It can be associated with the 2nd phase of the earth-timber period fort. The second one was $3.7 \mathrm{~m}$ wide. The northern section of the third ditch was identified $40 \mathrm{~cm}$ south of the second one. These can be linked to the stone period fort. The stone period apparently had double V shaped fossae as we could see in the northern praetentura. These ditches were filled and the fan shaped tower was built above them.

The tower extended approx. 10.5-11 m behind the rounded fort wall, the extreme width of outer curve was approx. 8.5-9 m. It is noteworthy that the distance between the fort wall and the first ditch was over $5.5 \mathrm{~m}$. The posterior wall of the trapezoidal tower was levelled in the late Roman period.

The northern gate of the fort (porta principalis sinistra) was investigated in trench V $\left(5 \times 1 \mathrm{~m}, \mathrm{~N}-\mathrm{W} 2^{\prime}\right)$ and in section II $(5 \times 5 \mathrm{~m})$. In trench V we found a section of the via principalis. The road level was $109.35 \mathrm{~m}$ a.s.1. It had a thick $(40-60 \mathrm{~cm})$ gravel layer and had been renewed twice. Above the gravelled road level a yellow clayey layer was observed. Horizontally laid bricks were found in this layer. A small 
section of another yellow clayey level was unearthed as well. These levels probably belonged to the late Roman period when the $\mathrm{U}$ shaped tower was built and this part of the road was used as its interior. The upper layers were cut by modern pits and thus the latest Roman layers were probably destroyed. A $40 \mathrm{~cm}$ wide stone drain was found below the road. Its stones, mixed with brick fragments, were set in clay. Fragments of a North Italian thin-walled cup fragments were found among the stones. The mortared bottom of the drain lay $108.12 \mathrm{~m}$ a.s.l. The drain was covered by smaller and larger limestone slabs (the largest is $120 \times 60 \mathrm{~cm}, 40 \times 60 \mathrm{~cm}$ on the average). In its fill contained a few Roman and prehistoric pottery sherds, as well as egg shell fragments. A stone channel measuring $45 \times 60 \mathrm{~cm}$ was uncovered in the southern end of the trench; this channel led the rain water into the drain. It consisted of two $U$ shaped carved stones. The road above it was covered by smaller stones.

Section II was opened $1 \mathrm{~m}$ east of the trench in order to investigate the western tower of the gateway. Here we could uncover the whole tower. Its external dimensions were $2.5 \times 3.7 \mathrm{~m}$, its internal dimensions were $1.3 \times 2.5 \mathrm{~m}$. The southern part of the tower remained more intact than the northern one where the stones of the wall had been removed to the foundations. The walls are $60 \mathrm{~cm}$ wide, and they survived to a height of $70-80 \mathrm{~cm}$. Its $90 \mathrm{~cm}$ wide entrance was found on the southern side (109.62 $\mathrm{m}$ a.s.1.). It had projecting footing, the foundation was $70 \mathrm{~cm}$ high. The base of its foundation lay $108.71 \mathrm{~m}$ a.s.l. It had limy and yellow clayey floor levels. There was no projecting part of the tower. The stones of the surviving wall and highest row of the foundation were set in mortar (6-7 rows remained), the stones of the foundation were set in clay. The characteristic feature of its ground-plan is that the eastern wall of the tower projects $40 \mathrm{~cm}$ eastwards $1.4 \mathrm{~m}$ north of the southeastern corner and served as a buttress for the gate. This projection was only $20 \mathrm{~cm}$ wide on the interior face of the wall. West of the tower we uncovered a section of the inner earthen rampart of the fort wall. It consisted of brown yellow clayey layers and grey earth. Its $3.8 \mathrm{~m}$ wide section was observed. In the rampart the mud walls of an earth-timber period structure were also uncovered. The adobe-walled building was only partly levelled when the stone fort was built and its layers were built in into the Wehrgang. The remnants of the levelled upper wall can also be seen in the section. Two $0.5 \mathrm{~m}$ wide walls can be seen at distance of $2.5 \mathrm{~m}$ from each other. Their surviving height is $50-70 \mathrm{~cm}$. The walls consisted of $25 \mathrm{~cm}$ wide 15-20 high grey mud bricks (2 rows beside each other). Under the rampart, $1.8 \mathrm{~m}$ below the present ground level, an Iron Age layer was found. We could not observe the fort wall in this section. Only its $1.2 \mathrm{~m}$ wide demolition layer was found in the northwestern corner, suggesting that the fort wall was totally robbed here. This also means that the tower did not have a projecting part. The demolition layer of a $1.3 \mathrm{~m}$ wide wall was unearthed in the northern section. The base of its foundation lay $108.73 \mathrm{~m}$ a.s.l. This wall had probably belonged to the western longitudinal wall of the U shaped tower which was added to the northwesten corner of the earlier tower. It was totally robbed and its addition can explain the robbing of the northern part of the earlier tower. The mixed layer containing stones and mortar in the northeastern part of the section belongs to this period. The floor levels of this period were not observed because of modern intrusions. A $50-60 \mathrm{~cm}$ thick fill 
containing gravel, sand and yellow clay was found in the interior of the rectangular tower. This fill can be observed in the southern section south of the tower as well, implying that the posterior part of the tower was not used in the late Roman period. It was filled and probably partly levelled.

\section{SELECTED FINDS (Figs 5-6)}

\section{Pottery}

Samian ware (identified by D. Gabler)

1. Body fragment of a Drag. 37 bowl. Hadr. M-Gaulish. N end of trench II, brownish mixed layer, $-1.4 \mathrm{~m}$.

2. Base fragment of a Drag. 18/31 plate. Hadr.-Ant. M-Gaulish. Ibid.

3. Rim fragment of Consp. 43 cup. N-It. Dom-Traian. N end of trench II, yellow mixed layer, $-0.8 \mathrm{~m}$.

4. Base fragment of Drag. 18/31. Ant. M-Gaulish. Ibid.

5. Body fragment of Drag. 18/31. Hadr.-Ant. M-Gaulish. Trench I, W of the wall, dark brown clay layer, $-1.8 \mathrm{~m}$.

6. Body fragment of Drag. 46. M-Gaulish. Ibid.

7. Body fragment of N-It. Samian ware. Ibid. (Fig. 5/2)

8. Body fragment of Drag. 37. Albucius. M-Gaulish, 140-170. W. part of trench II, dark brown mixed clay, $-1.5 \mathrm{~m}$.

9. Body fragment of a Drag. 33 cup. M-Gaulish. Ibid.

10. Body fragment of Drag. 37. M-Gaulish. Ibid.

11. Body fragment of Drag. 33. Hadr. M-Gaulish. Trench II, under the via sagularis.

12. Fragments of a Drag. 18/31 plate. Had-Ant. M-Gaulish. W. part of trench II, dark brown mixed clay, $-1.8 \mathrm{~m}$.

13. Body fragment of Drag. 37. Traian-Hadr. Martres-de-Veyire. W. part of trench II, dark brown mixed clay, $-1 \mathrm{~m}$.

14. Rim fragment of a Drag. 42 plate. Hadr. M-Gaulish. Ibid.

15. Fragment of a Drag. $18 / 31$ R plate. Ant. M-Gaulish. Ibid.

16. Fragment of Drag. 37. Hadr-Ant. M-Gaulish. Ibid.

17. Fragment of Drag 18/31. Hadr.-Ant. M-Gaulish. W part of trench, rubble layer.

18. Fragment of Drag. 33. Hadr.-Ant. M-Gaulish. Ibid.

19. Fragment of Drag 18/31. Hadr.-Ant. M-Gaulish. Trench I, brown clayey layer between the two walls.

20. Fragment of Drag 33. Ant. M-Gaulish. Ibid.

21. Body fragment of Drag. 37. Cinnamus or Paternus. Ant. M-Gaulish. W. part of trench II, dark brown mixed clay, $-1 \mathrm{~m}$.

22. Body fragment of Drag. 18/31. M-Gaulish. Ibid.

23. Fragment of Drag 33. Hadr.-Ant. M-Gaulish. W. end of trench I, rubble layer. 

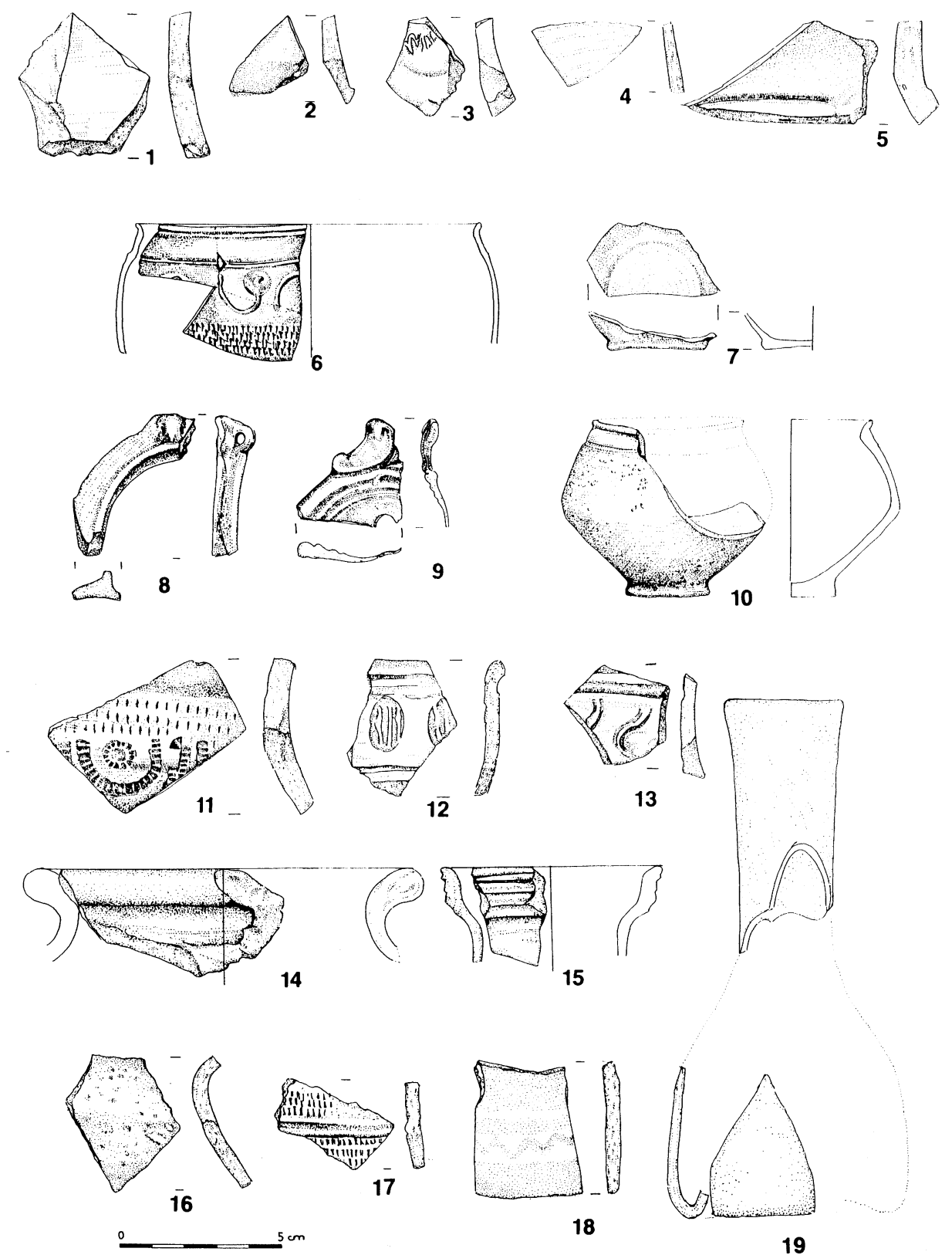

Fig. 5 

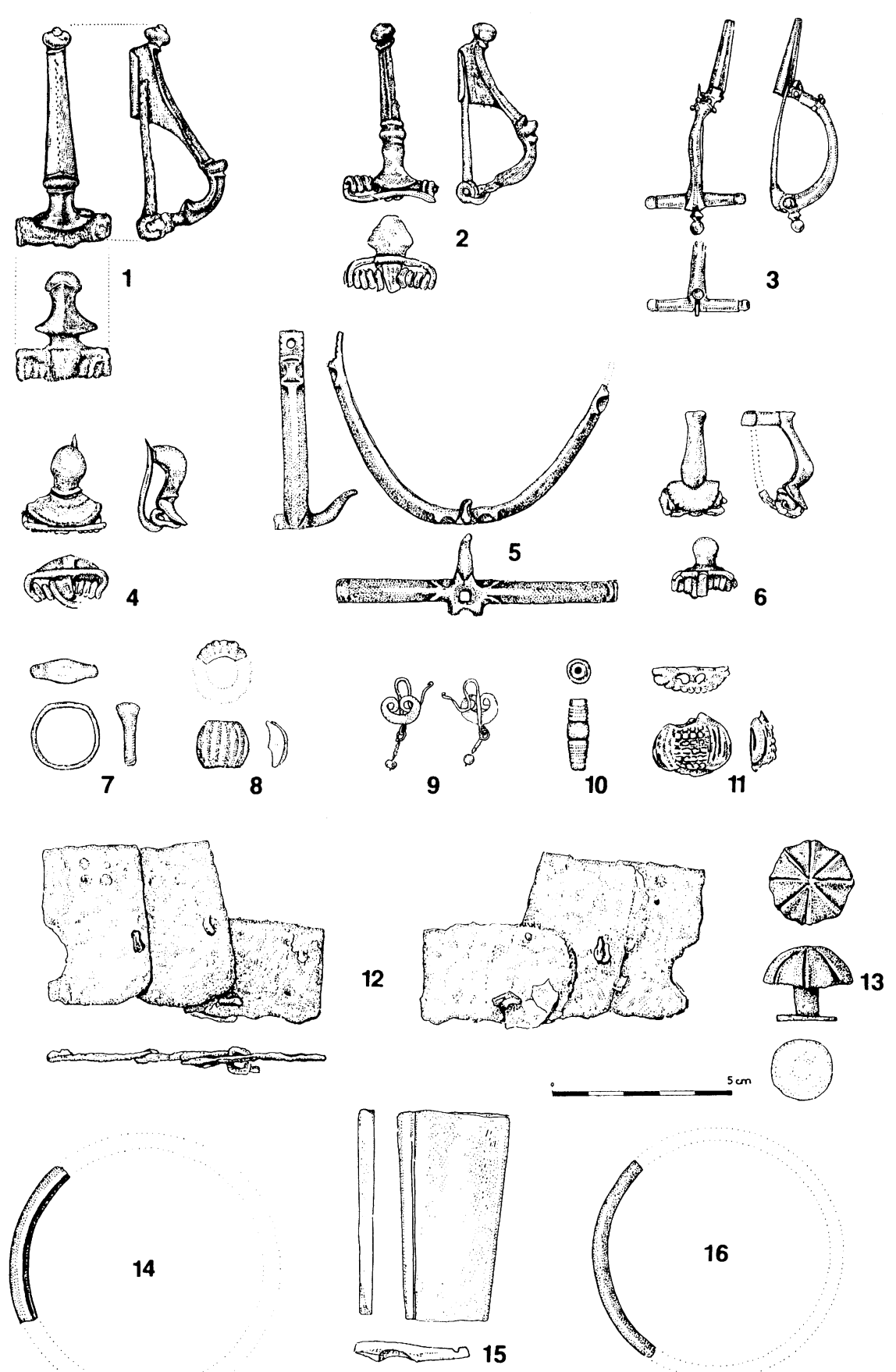

Fig. 6

Acta Ant. Hung. 41, 2001 
24. Fragment of Drag 37. Hadr.-Ant. M-Gaulish. Ibid.

25. Fragment of a Drag 27 cup. Hadr.-Ant. Pius. M-Gaulish. N. end of trench II, rubble layer.

26. Fragment of a Drag 42 plate. Hadr. M-Gaulish. W. part of trench II, rubble layer.

27. Fragment of Drag 36. Hadr.-Ant. M-Gaulish. N. end of trench II, rubble layer.

28. Fragment of Drag 37. Severus, Rheinzabern. Ibid.

29. Fragment of Drag 37. Dom-Trai. S.-Gaulish. N. end of trench II, mixed brown layer, $-1.3 \mathrm{~m}$.

30. Fragment of Drag 37. Hadr.-Ant. M-Gaulish. Ibid.

31. Fragment of Drag 37. Ant. M-Gaulish. Cinnamus. Ibid.

32. Fragment of Drag 33. Dom.-Traian. S-Gaulish. Ibid.

33. Base fragment of Drag. 18/31 M-Gaulish. Hadr.-Ant. Ibid.

34. Fragment of Drag. 37. Hadr.-Ant. M-Gaulish. Ibid.

35. Fragment of Drag. 18/31. M-Gaulish. Ibid.

36. Rim fragment of Drag. 33. Hadr.-Ant. M-Gaulish. W. part of trench II, dark brown mixed clay, $-1.8 \mathrm{~m}$.

37. Fragment of a Drag. 33. cup. M-Gaul. Hadr.-Ant. Trench II, humus.

38. Rim fragment of Drag. 37. S.-Gaul. Banassac. Traian-Hadrian. Section I, robbing layer.

39. Rim fragment of Drag. 37. Westerndorf. Ibid.

40. Body fragment of Samian ware. M-Gaul. Ibid.

41. Body fragment of Samian ware. M-Gaul. Ibid.

42. Fragment of a Drag. 31 plate. Later 2nd century. Rheinzabern. Ludowici SB. Trench IV, demolition layer of the fan shaped tower.

43. Fragment of a Drag. 33 cup. Rheinzabern. Later 2nd century. Section I, rubble layer.

44. Body fragment Drag. 37. M-Gaul. Ant. Ibid.

45. Fragment of Drag. 18/31. M-Gaul. Hadr.-Ant. Section I, below the floor level.

46. Fragment of Drag. 37. Cibisus, Ittenweiler. Ant. Praetentura, fill of the $\mathrm{N}$ fossa.

47. Fragment of Drag. 37. M.-Gaul. Ant. Section I, fill of the fossa.

48. Fragment of Drag. 46. Rheinzabern. Mid-2nd century. Section I, fill of the N fossa, $-1.8 \mathrm{~m}$.

49. Fragment of Drag. 37. S.-Gaul. Banassac, Natalis? Traian-Hadr. Ibid.

50. Fragment of Drag. 37. S.-Gaul. Dom.-Traian. Ibid.

51. Fragment of Drag. 37. M.-Gaul. Hadr.-Ant. N. end of trench IV, mixed layer, $-1 \mathrm{~m}$.

52. Fragment of Drag. 36. S.-Gaul. Dom.-Hadr. Trench III, demolition layer of the fort wall.

53. Fragment of a Drag. 33 cup. M.-Gaul. Hadr.-Ant. Section II, inner earthen rampart of the fort wall. (Fig. 5/5)

54. Body fragment of Drag. 37. M.-Gaul. late Hadr.-Ant. Trench V, gravelled road level. (Fig. 5/3) 
55. North-Italian body fragment Conspectus? Claud.-Vesp. Trench IV, fill of the earth-timber period fossa. (Fig. 5/1)

56. Fragment of Drag. 18/31. M.-Gaul. Hadr.-Ant. Trench III, rubble layer.

57. Fragment of Consp. 20. plate. North-It. Claud.-Vesp. Ibid. (Fig. 5/4)

58. Fragment of a Drag. 37 bowl. Rheinzabern. Late 2nd-earlier 3rd century. Section I, rubble layer.

59. Fragment of Drag. 18/31. M.-Gaul. Hadr.-Ant. Section I, fill of the fossa, $-1.8 \mathrm{~m}$.

60. Fragment of Drag. 18/31. M.-Gaul. Hadr.-Ant. Ibid.

61. Fragment of a Drag. 37 bowl. Rheinzabern. Late 2nd-earlier 3rd century. Ibid.

62. Fragment of Drag. 18. S.-Gaul. Traian.-Hadr. Ibid.

63. Fragment of Drag. 33. M.-Gaul. Hadr.-Ant. Ibid.

64. Fragment of Drag. 18/31. S.-Gaul. Hadr. Ibid.

65. Fragment of Drag. 30. Rheinzabern. Ant. Section I, rubble layer, $-0.8 \mathrm{~m}$.

66. Fragment of Drag. 30. Rheinzabern. Ant. Ibid.

67. Fragment of Drag. 33. M.-Gaul. Hadr.-Ant. Ibid.

68. Fragment of Drag. 37. M.-Gaul. Hadr.-Ant. N end of trench IV, rubble layer.

69. Fragment of Drag. 37. S.-Gaul. Natalis. Traian-Hadr. Section II, robbing layer.

70. Fragment of a Drag. 18/31R plate. Rheinzabern. Ant. Trench V, humus.

\section{Imported ware}

1. Fragments of a North-Italian thin-walled cup with barbotine and rouletted decoration (Fabrikat E). Flavian. Trench V, between the stones of the channel below the road. ${ }^{13}$ (Fig. 5/6)

2. Base fragment of a dark grey thin-walled cup (Fabrikat E). D: $3 \mathrm{~cm}$. Trench IV, beside the foundation of the fort wall. (Fig. 5/7)

\section{Local ware}

Fine ware

1. Fragments of an egg shaped rough-cast cup. Diam: $2.2 \mathrm{~cm}, \mathrm{H}: 4.8 \mathrm{~cm}$. Section I, fill of the fossa. (Fig. 5/10)

2. Grey metallic slipped body fragment with S shaped stamped decoration. Northern part of trench I, brown mixed layer, $-1.5 \mathrm{~m}^{.4}$ (Fig. 5/13)

${ }^{13}$ GASSNER, V.: Feinware aus Carnuntum. Carnuntum Jahrbuch 1990, 256-261.

${ }^{14}$ SALAMON, Ä.: Spätrömische gestempelte Gefässe aus Intercisa. FolArch 20, 1969, 53, Abb. 1; for the stamp, cp. GudEA, N.: Porolissum. Un complex daco-roman la marginea de nord a imperiului roman. II. Săpături şi cercetări arheologice până în 1977 - Porolissum. Ein dakisch-römischer archäologischer Komplex an der Nordgrenze des römischen Reiches I. Archäologische Ausgrabungen und Forschungen bis 1977. Zalău 1989, Pl. XXV. 60, XL. 217-226; Forschungen in Gorsium in den Jahren 1987-1989. Alba Regia 25, 1995, 359, No. 322. 
Pannonian grey slip ware

1. Orange coated body fragment with stamped decoration (ovolo). N. part of trench II, brown mixed layer. (Fig. 5/12)

2. Grey coated body fragment with stamped decoration. Ibid.

3. Grey coated body fragment with stamped decoration. Section I, rubble layer.

4. Base fragment of bowl with stamped decoration. Trench IV, gravelled road level.

5. Rim fragment of bowl with horizontal rouletting and stamped decoration. $5 \mathrm{x}$ $7.5 \mathrm{~cm}$. Section I, demolition layer, $-1.6 \mathrm{~m}$. (Fig. 5/11)

6. Rim fragment of bowl. $3 \times 4 \mathrm{~cm}$. Ibid.

7. Orange coated base fragment $\mathrm{N}$ part of trench II, mixed layer, $-0.8 \mathrm{~m}$.

Colour coated and coarse pottery

1. Base fragments of a jug with red coating. Section I, fill of the ditch, $-1.8 \mathrm{~m}$.

2. Slightly everted rim fragment of a pot with red coating. Trench $\mathrm{V}$, between the stones of the channel under the road. (Fig. 5/14)

3. Rim fragment of grey pot with Kerbschnitt on the neck. Trench II, level of the oven.

4. Body fragment of a yellow fabric jug with the stump of the handle. Ibid.

5. Fragments of a yellow fabric jug. Trench II, firing plate of the oven.

6. Body fragment of a red coated beaker. Trench II, humus soil beside the foundation of the fort wall.

7. Fragment of a yellow fabric pot with horizontally everted rim. Ibid.

8. Rim fragment of a flagon with double ring in yellow fabric. Trench II, via sagularis, beside the drain. ${ }^{15}$ (Fig. $5 / 15$ )

9. Neck fragment of a flagon with orange-red coating and ribbed handle. Northern part of trench II, brown mixed clayey layer, $-1.4 \mathrm{~m}$.

10. Rim fragment of a yellow fabric mortarium. Ibid.

11. Rim and base fragment of a mortarium with orange-red coating. Trench I, rubble layer of the roof.

12. Spindle whorl carved from a grey coarse pottery sherd. D. $3.6 \mathrm{~cm}$. Trench $\mathrm{W}$ of the walls, rubble layer.

13. Horizontallyeverted rim frags of a bowl with red coating and stamped, Sshaped decoration. Section I, demolition layer, $-1 \mathrm{~m}^{16}$

${ }^{15}$ Cf. GABLER, D.: The Roman fort at Ács-Vaspuszta on the Danubian limes. BAR IS 531. Oxford 1989, 279, No. 90, Fig. 103.

${ }^{16}$ See note 14 and BARKÓCZI, L.: Császárkori kelta edényégető telep Bicsérden - Celtic pottery kilns from the times of the Roman Empire at Bicsérd. FolArch 8, 1956, 71, No. 11, Fig 24/1, Pl. XX/1-2. 


\section{Lead glazed ware}

1. Green body fragment of a jug. Trench IV, demolition layer of the fan-shaped tower. (Fig. 5/16)

2. Green body fragment. Section I, rubble 1, from under the humus.

3. Yellowish-green body fragment of a jug. Trench V, rubble layer.

4. Orange red body fragment of a bowl with rouletted decoration. Ibid. ${ }^{17}$ (Fig. $5 / 17)$

5. Green body fragment. Section I, fill under the first floor level.

6. Base fragment of a jug. The glaze can only be observed in some places. Trench II, destruction level of the fort wall.

\section{Burnished pottery}

1. Body fragment decorated with a wavy line. 4 x $3.5 \mathrm{~cm}$. Section I, demolition layer, $-1.6 \mathrm{~m}^{18}$

2. Body fragment. Section I, floor level 1.

3. Rim fragment of a pot with rouletting. Northern part of trench II, brown mixed clayey layer, $-1.4 \mathrm{~m}$. LTD form. ${ }^{19}$

4. Body fragment decorated with a wavy line. Trench II, mixed layer, $-0.5 \mathrm{~m}$.

\section{Lamps (identified by Zs. Pongrácz)}

1. Nozzle of a factory lamp (Firmalampe). 3rd century. Trench I, brown clayey layer between the foundation of the two walls. ${ }^{20}$

2. Discus fragment of a voluta lamp with metallic light-red slip. Mid-1st century. Trench II, beside the foundation of the fort wall, Wehrgang. (Fig. 5/9)

3. Discus fragment of a factory lamp (Firmalampe). Later 1st century. Section I, fill of the fossa, $-1.8 \mathrm{~m}^{21}$ (Fig. $5 / 8$ )

4. Base of a factory lamp. 5 x $4 \mathrm{~cm}$. Later 1st century. Section I, below the floor level. ${ }^{22}$

${ }^{17}$ Glasierte Keramik in Pannonien. Székesfehérvár 1992, 43, Abb. 6. 4-6.

${ }^{18}$ OttomÁnyi, K.: Fragmenten der spätrömischen eingeglattenen Keramik in Pannonien. DissArch II. 10. Budapest 1982, T. XIX. 7.c, XX. 7.d.

${ }^{19}$ BÓNIS, op. cit. (note 2), 87, T. XI. 3, 5; BÓNIS, É.: Die spätkeltische Siedlung GellérthegyTabán in Budapest. ArchHung 47. Budapest 1969, 191-193, Abb. 60. 5, 64. 20, 97. 11.

${ }^{20}$ LOESCHKE, S.: Lampen aus Vindonissa. Zürich 1919, type X.

${ }^{21}$ LOESCHKE, op. cit. (note 20), type IX.

${ }^{22}$ IVÁNYI, op. cit. (note 2), type XXII. 


\section{Metal finds}

1. Pelta shaped golden earring with a pearl pendant. Trench I, 1st floor level. ${ }^{23}$ (Fig. 6/9)

2. Small bronze tube, of rolled sheet. Trench I, fill between the two floor levels. ${ }^{24}$

3. Knee shaped brooch. N. part of Trench II, upper rubble layer. ${ }^{25}$ (Fig. 6/4)

4. Silver gilt crossbow-brooch. Trench I, rubble layer above the 2 nd floor level. ${ }^{26}$ (Fig. 6/3)

5. Bronze hook. N part of trench II, dark brown clayey layer, $-1.8 \mathrm{~m}$.

6. "Kräftig profilierte" bronze brooch. N part of trench II, dark brown clayey layer, -1.4 m. $^{27}$ (Fig. 6/1)

7. "Kräftig profilierte" bronze brooch. N part of trench II, dark brown clayey layer, $-1.5 \mathrm{~m}^{28}$ (Fig. 6/2)

8. Silver ring. Diam: $1.9 \mathrm{~cm}$. Trench I, 2nd floor level. ${ }^{29}$ (Fig. 6/7)

9. Bronze knee shaped brooch. Ibid. ${ }^{30}$ (Fig. 6/6)

10. Quadrate lead weight. $4.5 \times 3.5 \times 3 \mathrm{~cm}$. Ibid.

11. Bronze spur. $8 \times 5 \mathrm{~cm}$. Section I, below the floor level. ${ }^{31}$ (Fig. 6/5)

12. Three scale fragments of an iron scale armour (lorica squamata) with bronze rivets. $5 \times 6.5,2 \times 3 \mathrm{~cm}$, scale: $3 \times 4.5 \mathrm{~cm}$. Northern part of trench II, mixed layer, $-0.8 \mathrm{~m}^{32}$ (Fig. 6/12)

13. Mushroom shaped bronze mount. Diam: $2.5, \mathrm{H}: 1.8 \mathrm{~m}$. Section II, inside the tower, sandy fill. ${ }^{33}$ (Fig. 6/13)

14. Fragment of circular casket mount decorated with concentric circles. $3,2 \times 2.2 \mathrm{~cm}$. Trench III, demolition layer. ${ }^{34}$

${ }^{23}$ Cf. Marshall, H.: Catalogue of the jewellery in the Department of Antiquities, British Museum. London 1911, Nos 2364-2365. The earring will be published by M. Dági.

${ }^{24}$ GABLER, op. cit. (note 1), 179, Nos 20-23.

${ }^{25}$ PATEK, E.: A pannoniai fibulatipusok elterjedése és eredete - Die Verbreitung und der Herkunft der römischen Fibeltypen von Pannonien. DissArch II. 19. Budapest 1942, 56-62, 130-137, 298, T. XXIII. 11-12; JoBST, W.: Die römischen Fibeln aus Lauriacum. Foschungen in Lauriacum 10. Linz 1975, Nos 162, 166-167, 66-67.

${ }^{26}$ TótH, op. cit. (note 2), 33, 58, T. 20. a; JoBST, op. cit. (note 25), 90-91, 181, No. 222, T. 30, 62.

${ }^{27}$ PATEK, op. cit. (note 25), 21-26, 91-97, 283, 172-174, T. IV. 2-5; JOBST, op. cit. (note 25), Nos $14,133,33-34$.

${ }^{28}$ JOBST, op. cit. (note 25), Nos 52, 41-42, 142 .

${ }^{29}$ Intercisa II (Dunapentele). Geschichte der Stadt in der Römerzeit. ArchHung 36. Budapest 1957, 414-415, No. 10, 19, T. LXXVIII. 6-7.

${ }^{30}$ JoBST, op. cit. (note 25), Nos 158, 166, 66-67.

${ }^{31}$ Carnuntum I. Das Erbe Roms an der Donau. Wien 1992, 200, Nos 202, 204-206. There is an unpublished spur from Annamatia in the Intercisa Museum (Inv. no. 74.27.42).

${ }^{32}$ Bishop, M. C.-Coulston, J. C.: Roman military equipment. Aylesbury 1989, 32, 46, Fig. 33. 2-3; RoBinson, H. R.: The armour of imperial Rome. Thetford 1975, 153-159, Pl. 436.

${ }^{33}$ OLDENSTEIN, J.: Zur Ausrüstung römischer Auxiliareinheiten. Studien zu Beschlägen und Zierat an der Ausrüstung des römischen Auxiliareinheiten des obergermanisch-raetischen Limesgebietes aus dem zweiten und dritten Jahrhundert n. Chr. BRGK 57, 1976, 168, 256, No. 483.

${ }^{34}$ Intercisa II (note 29), 355, Abb. 68, No. 144. 


\section{Coins (identified by L. Thúry and M. Torbágyi)}

1. HS. Nerva. 97. $B M C$ III, 112. Trench I, E of the wall, yellow clayey layer, $-1.1 \mathrm{~m}$.

2. Ant. Elagabalus. 219. $B M C \mathrm{~V}, 114$. Trench I, E of the wall, rubble layer of the roof.

3. Den. Sev. Alex. 223. BMC VI, 117-12. Ibid.

4. Aes 3. II. Constantius. 348-359. RIC VIII. Trench II, fill of the fossa.

5. Aes 2. II. Constantius. 350. RIC VIII, 291. Trench I, posthole in the wall.

6. Aes 2. II. Constantius. 350. RIC VIII, 284. Ibid.

7. Aes 2. II. Constantius. 351-54. RIC VIII, 337. Ibid.

8. Aes 2. II. Constantius. 350. RIC VIII, 350. Trench I, E of the wall, rubble layer of the roof.

9. Ant. Victorinus. 269-271. RIC V/2, 59. N part of Trench II, upper rubble layer.

10. Aes 3. Constantinus. 320. RIC VII, 148. Stray find, beside trench I.

11. Aes 3. Crispus. 320-321. RIC VII, 161. Section I, yellow floor level below the humus.

12. Aes 3. Valens. 367-375. RIC IX, 15b/10. Section I, demolition layer, $-1 \mathrm{~m}$.

13. Ant. divus Claudius. 270. Section II, robbing of the tower wall.

14. Ant. Gallienus. 262-267. RIC V/1, 553. Ibid.

15. As. 2nd century. Ibid.

16. Aes 3. Valentinianus. 364-375. RIC IX, 17, 24/12. Section II, black demolition layer.

17. Aes 2. Constantinus. 313-315. RIC VII, 5. Section I, below the floor level.

18. HS. Traianus. 104-111. BMC III, 800. Section II, inside the tower, sandy fill.

19. Aes 3. Valens. 367-375. RIC IX, 15b/10. Ibid.

20. Ant. Gallienus. 259-267. RIC V, 507k. S. end of trench IV, rubble layer.

21. Dup. Traianus. 98-117. Trench III, brown mixed layer, $-1 \mathrm{~m}$.

22. Aes 4. II. Constantius. 337-341. LRBC I, 693. Section I, fill of the fossa, $-1.8 \mathrm{~m}$.

23. Aes 2. Licinius. 313-315. RIC VII, 8. Trench IV, robbing of the fan shaped tower.

24. Aes 3. Const.-dyn. 351-361. Ibid.

25. Aes. 4th century. Section II, rubble layer.

26. Aes. 4th century Ibid.

27. Aes 2. Iupp. Cons.-type. 307-318. Trench III, brown mixed layer, $-1 \mathrm{~m}$.

28. Aes 4. Constantinopolis. 330-337. Trench III, rubble layer.

29. Aes 3. Valens. 367-365. RIC IX, 14b/10. Section I, rubble layer.

30. Aes 3. Constantinus. 313-318. Ibid.

31. Aes 3. Sons of Constantinus. 320-324. Ibid.

32. Aes 3. Constantinus II. 320-324. Ibid.

33. Dup. Vespasianus. 71. BMC II, 589. Ibid.

34. Ant. Probus. 276-282. RIC V/2, 158 F1a. Section II, rubble layer.

35. Aes 3. Valens. 364-367. RIC IX, 7b/2. Section I, rubble layer. 
36. As. Traianus. 98-102. Section II, black demolition layer.

37. Aes 3. Valentinianus. 364-375. Ibid.

38. As. Hadrianus. Trench III, brown mixed layer, $-0.8 \mathrm{~m}$.

39. Aes 3. Constans. 346-350. LRBC, 626. Ibid.

40. Aes. Constantius II. 355-361. $L R B C, 1684$. Ibid.

41. Aes 2. Constantius II. 350. LRBC, 1173. Ibid.

42. 2 Kreuzer. Mar. Ther. 1762. Section I, demolition layer, $-0.8 \mathrm{~m}^{35}$

\section{Glass}

1. Two-channelled glass cameo. $2.1 \times 1.5 \times 0.6 \mathrm{~cm}$. Trench III, brown mixed layer, $-1 \mathrm{~m}^{36}$ (Fig. 6/11)

2. Fragment of a grooved greenish-blue bead. $1.3 \times 1.5 \mathrm{~cm}$. Section II, mixed layer $\mathrm{S}$ of the tower. ${ }^{37}$ (Fig. 6/8)

3. Fragment of a black glass armlet with D shaped section. Diam: $0.7 \mathrm{~m}, \mathrm{~L}: 4.3 \mathrm{~cm}$. Section II, rubble layer. (Fig. 6/14)

4. Fragment of a light green armlet. Diam: $0.5 \mathrm{~m}, \mathrm{~L}: 5.5 \mathrm{~cm}$. Ibid. (Fig. 6/16)

5. Base and neck fragments of a white flagon. Diam: $3.7 \mathrm{~cm}, \mathrm{H}: 7.4 \mathrm{~cm}, 4$ x $4 \mathrm{~cm}$. Section I, demolition layer. ${ }^{38}$ (Fig. 5/19)

6. Fragment of a greenish ribbon handle. Trench I, W of the wall, dark brown clayey layer.

7. Body fragment of a glass decorated with chiselled horizontal marks. Section I, fill of the ditch, $-1.8 \mathrm{~m}^{39}$

8. Rim fragment decorated with oblique grooves. $2.5 \times 3 \mathrm{~cm}$. Trench IV, mixed brown layer, beside the fort wall.

\section{Bone}

1. Cylindrical turned bone bead with roll moulding and bead row (astragalos) motif. Trench I, E of the wall, destruction layer of the roof. ${ }^{40}$ (Fig. 6/10)

2. Rectangular bone plate with horizontal incised line. Reverse of a scabbard chape. $5.8 \times 3.1-2.2 \times 0.4 \mathrm{~cm}$. Section I, under the floor level. ${ }^{41}$ (Fig. $6 / 15$ )

${ }^{35}$ Cf. HuSZÁr, L.: Münzkatalog Ungarns von 1000 bis heute. Budapest 1979, No. 1758.

${ }^{36}$ Cf. GeszTELYI, T.: Kettőscsatornájú üvegkameók - Glaskameen mit zwei Kanälen. ArchÉrt 123-124, 1996-1997, 63-74; Spätrömische Glaskameen mit zwei Kanälen. ActAnt 38, 1998, 129-136.

${ }^{37}$ Cf. Intercisa II (note 29), 442, Abb. 94. 43, 47.

${ }^{38}$ BARKÓCZI, L.: Pannonische Glasfunde in Ungarn. StudArch 9. Budapest 1988, 119, No. 215, Variant b; FÜLEP, F.: Sopianae. The history of Pécs during the Roman era, and the problem of the continuity of the late Roman population. Budapest 1984, 130, grave L/103, Fig. 109.

${ }^{39}$ BARKÓCZI, op. cit. (note 38), 90, No. 126.

${ }^{40}$ Bíró, M.: Adalékok Brigetio csontiparához - Contribution to the bone-industry of Brigetio. Komárom-Esztergom megyei múzeumok közleményei 5, 1997, 182, Fig. 32.

${ }^{41}$ OldENSTEIN, op. cit. (note 33), 245, Nos 166-167, BíRÓ, M. T.: The bone objects of the Roman collection. Catalogici Musei Nationalis Hungarici. Series Arch. II. Budapest 1994, 70, No. 20, Pl. IV. 
Stamped tiles

1. Teg. CHOR VII BR[. W: $2.8 \mathrm{~cm}$. Trench I, E. of the wall, destruction layer of the roof.

2. Imbr. W: $1.8 \mathrm{~cm}$. (retr.) LEG II AD. Ibid.

3. Teg. W: $2.5 \mathrm{~cm}$. ] II AD. Trench II, destruction layer of the fort wall.

4. Imbr. W: $1.6 \mathrm{~cm}$. (retr.) EXERPAN[. Trench I, fill between the two floor levels.

5. Imbr. W: $1.8 \mathrm{~cm}$. ]OH V[. N end of trench II, below the humus.

6. Teg. COH VII BR. Trench V, renewed road level.

7. Teg. TEREN. W: $3.2 \mathrm{~cm}$. Section II, robbing layer.

8. Teg. ]H VII B[. W: $2.8 \mathrm{~cm}$. Section I, below the floor level.

9. Teg. ]P DV[. W: $1.8 \mathrm{~cm}$. N. part of section I, demolition layer, $-1.6 \mathrm{~m}$.

10. Teg. ]RIB[. W: $3.8 \mathrm{~cm}$ Section I, rubble layer, - $-0.8 \mathrm{~m}$ (Quadriburgium-type ${ }^{42}$ ).

11. Teg. COH [. W: $2.8 \mathrm{~cm}$. Trench III, demolition layer of the fort wall.

12. Teg. [H VII BR. W: $2.8 \mathrm{~cm}$. Ibid.

13. Teg. COH VII BR. W: $3.5 \mathrm{~cm}$. Ibid.

14. Imbr. ]XERPANINF. W: $2.1 \mathrm{~cm}$. Ibid.

15. Teg. ]DV[. Th: $2 \mathrm{~cm}$. Section II, robbing layer.

\section{Carved stones}

Quernstone fragments. Tufa. 13 × $21 \mathrm{~cm}, 14$ x $13 \mathrm{~cm}, 13$ x $10 \mathrm{~cm}, 14 \times 21 \mathrm{~cm}$. H: 10-12 cm. Trench I, rubble layer of the roof.

\section{SUMMARY}

On the basis of our excavations we can date the very beginnings of the fort to Vespasian's reign. The North Italian Samian ware (Cat. Nos 3, 7, 55, 57) and thin-walled finds, the 1st century lamps (Cat. Nos 2-4) and coins (Cat. No. 33) also confirm this early date. ${ }^{43}$ This date would also explain the etymology of Intercisa. ${ }^{44}$ On the basis of the ditches on the southern and western side and of the mud walls on the northern side, the 1st period earth-timber fort had approximately the same dimensions as the stone fort. The North Italian Samian ware fragment (Cat. No. 55) found in the fill of the $\mathrm{V}$ shaped ditch clearly proves that this ditch can be assigned to the earliest period of the castellum. On the basis of the 2 nd ditch in section I, $5 \mathrm{~m}$ south of the first one, the fort had another earth-timber period. The thin-walled fragments from trench $\mathrm{V}$

${ }^{42}$ SZILÁGYI, J.: Inscriptiones tegularum Pannonicarum. DissPann II. 1. Budapest 1933, 104,

${ }^{43}$ For the Flavian E-Pannonian forts, cp. GABLER, D.: The Flavian limes in the Danube bend (Eastern Pannonia). CommArchHung 1999, 75-86. These finds are some 30-40 years earlier than the earlier published Samian ware fragments.

${ }^{44}$ For the etymology of Intercisa, cp. VISY, op. cit. (note 1), 106.
} 
indicate that the via principalis of these periods ran under the road of the stone period. Comparable mud walls were unearthed in the earthen rampart of the fort at Leányvár. ${ }^{45}$ These walls were also part of a military barrack. The levelled upper parts of the walls and the floor level are also very similar.

The first known garrison of the fort was probably the cohort I Thracum c. R. p. f. This troop was stationed here between $106-118 / 19 .^{46}$ The next known garrison was the cohort I Thracum Germanica eq. that was stationed here from $131-132 .{ }^{47}$ This is confirmed by the finds, primarily the stamped bricks. ${ }^{48}$ The CIL III 10639 milestone found in the area of the fort mentions the cohort with the imperial epithet Maximiniana. This is the latest mentioning of the cohort. The CIL III $3326=10302=R I U$ 1157, IGRR I 534 and AÉp 1993, 1298 inscriptions mention soldiers of the cohort, but they do not mention the troop. The CIL III $3319=10299=$ RIU 1018 grave inscription from Bölcske can also be dated to this period of the cohort. The RMD II 102-103 military diplomata from Lussonium, dated to 157 , belonged to the veterans of this troop. Unfortunately, the RMD II 113 military diploma found at Annamatia is fragmentary.

We found dating evidence for the building of the stone fort in the earthen rampart of the northern fort wall and in the level of the via principalis. A Drag. 33 cup and a Drag. 37 bowl fragment (Cat. Nos 53-54) from the Hadrian-Antonine period were found here. These dates indicate that the fort was rebuilt in stone during the Antonine period. On the basis of its groundplan the gate tower does not belong to the well-known rectangular projecting gate tower-type of the period after the Marcomannic wars. ${ }^{49}$ The tower of Annamatia was rectangular, but it did not have a projecting part. The via principalis was placed approx. $60 \mathrm{~m}$ east of the northwestern corner of the fort. The fort wall connected the tower by the northwestern corner. It is unclear whether the direction wall was parallel to the tower or whether it joined the tower at an obtuse angle because the fort wall is totally robbed. We do not know whether they were built in the same period or not. The thin walls and the renewed road levels of the via principalis do not confirm the latter. These very thin $(60 \mathrm{~cm}$ wide) walls are surprising, but the southern gate of the neighbouring fort at Lussonium had similar towers. ${ }^{50}$ Its walls were also $60-90 \mathrm{~cm}$ wide. These towers also belong to the same rectangular type without any projecting part, suggesting that they were built in the

\footnotetext{
${ }^{45}$ RAJTÁR, J.: Das Holz-Erde-Lager aus der Zeit der Markomannenkriege in Iža. Problemen der relativen und absoluten Chronologie ab Latènezeit bis zum Frühmittelalter. Kraków 1992, 154-155, Abb. 8.

${ }^{46}$ Régészeti kézikönyv - Handbook of archaeology. Budapest 1990, 81; Von Augustus bis Attila. Leben am ungarischen Donaulimes. Stuttgart 2000, 47; LÖRINCZ, B.: Die Hilfstruppen der römischen Provinz Pannonien in der Prinzipatszeit. Wien 2001. 40, No. 43 (forthcoming).

${ }^{47}$ Régészeti kézikönyv, 81; LÖRINCZ, op. cit. (note 46), 41, No. 45, Cat. Nos 463-466.

${ }^{48}$ LÖRINCZ, op. cit. (note 2), 16, No. 3; VISY, op. cit. (note 1), 77, Fig. 109. 2.

${ }^{49}$ BECHERT, T.: Römische Lagertore und ihre Bauinschriften. Ein Beitrag zur Entwicklung und Datierung kaiserzeitlicher Lagertorgrundrisse von Claudius bis Severus Alexander. BJb 171, 1971, 242259; GABLER, D.: A dunai limes I-II. századi történetének néhány kérdése - Some remarks on the history of the Danubian limes of the first and second century. ArchÉrt 104, 1977, 145-175; GABLER, op. cit. (note 15), 64-67.

${ }^{50}$ VISY, op. cit. (note 1), 86; VISY, Zs., TörténÉsz 2/2, 1994, 4-5.
} 
same period. Visy also dated it to the 2nd century. The only difference is that the tower of Baracs had relatively high ascending walls. The only similar Pannonian towers of this type were unearthed at Odiavum and Albertfalva. ${ }^{51}$ Unfortunately, the results of the excavations of these forts are still unpublished, but the fragmentary building inscription of the fort found at Odiavum records that the fort was built in stone under Antoninus Pius. ${ }^{52}$ This date also seems acceptable for the other forts and neither does the dating evidence from Baracs contradict this hypothesis. This earlier type was recently observed by Zs. Visy. ${ }^{53}$ This tower type can generally be dated earlier in the other provinces of the empire as well. ${ }^{54}$

The groundplan of the tower at Annamatia also has another unusual feature. The eastern wall had eastward projections towards the via principalis which narrowed the road. The only parallels to this projection were observed in the auxiliary fort at Brecon Gaer ${ }^{55}$ where the western gateway had similar projections. The northeastern gate of the legionary fort at Novaesium also had similar projections, but these were built because of the entrance of the towers. ${ }^{56}$ The western towers of the porta principalis dextra of the Dacian auxiliary fort at Gyalu and the porta principalis dextra at Sulz had an only partly widened wall. ${ }^{57}$ The difference in the case of the tower at Baracs is that the projection narrowed the outer half of the gateway. The projection could be used as a buttress as well. The similar additions to the gate towers at Obernburg and Amsareddi (L shaped addition to the southern gate) were used this way. ${ }^{58}$ The southern gate of Bu Ngem was also similar to the gate of Annamatia. ${ }^{59}$

In trench $\mathrm{V}$ we unearthed a covered drain below the road. Similar drains or ditches, running in direction of the Danube, can be observed in almost all Pannonian auxiliary forts. ${ }^{60}$ More important is the channel of the drain that collected and led the rainwater of the road into the drain. It consisted of two connecting $U$ shaped carved stones. Similar channels were found in the legionary fort of Vindobona and in the

${ }^{51}$ Der römische Limes in Ungarn. Székesfehérvár 1976, 38-39, 90-91; NAGY, T.: Az Albertfalva Hunyadi János úti római település. Budapest müemlékei II. Budapest 1962, 519-521. For the date of the building in stone of the fort, cp. VISY, op. cit. (note 1), 59.

${ }^{52}$ RégFüz 26, 1973, 28.

${ }^{53}$ VISY, ZS.: Some notes on the defence system of Pannonia in the 2 nd and 3rd centuries A. D. $\mathrm{La}$ Pannonia e l'Impero Romano. Roma 1994, 91.

${ }^{54}$ BECHERT, op. cit. (note 49), 218-239; LANDER, J.: Roman stone fortifications. Variation and change from the First century A. D. to the Fourth. BAR IS 206. Oxford 1984, 67-92.

${ }^{55}$ WHEELER, R. E. M.: The Roman fort near Brecon. Y Cymmrodor 26. London 1926; LANDER, op. cit. (note 54), 76, Fig. 59. The fort was built in stone in the Antonine period, but Lander believes that the projection is a later addition.

${ }_{56}$ BECHERT, op. cit. (note 49), 222, Abb. 6. 2.

${ }^{57}$ ISAC, D.: Die Kohorten- und Alenkastelle von Gilău. Zalău 1997, 3-40, T. XV; ORL Abt.Nr.B 61a (1987), 4, T. II.

${ }^{58}$ ORL Abt. B. Nr. 35 (1903), 6-7, 10-12; GREGORY, S.: Roman military architecture on the Eastern Frontier II. Amsterdam 1997, 182-183, Fig. D10.1.

${ }^{59}$ REBUfFAUT, R.: Notes sur le camp romain Gholaia (Bu Ngem). LibyanSt 20, 1989, 155-167.

${ }^{60}$ Kovács, P.: Matrica. Excavations in the Roman fort at Százhalombatta (1993-1997). Budapest 2000, 59-60. 
auxiliary fort of Carnuntum ${ }^{61}$ and they can be found in civilian towns, e.g. at Aquincum as well. ${ }^{62}$

The fort walls were approx. $1 \mathrm{~m}$ wide. This width corresponds to the other Pannonian fort walls. ${ }^{63}$ The inner building of trench I can be identified as a military barrack. On the basis of the finds (crossbow- and knee shaped brooches, silver ring, golden earring) the construction periods of the building can be dated to between the 3rd century and the earlier 4th century The coin of Constantius II (Cat. No. 8) from the destruction layer of the roof indicates the date of its destruction. The building had an earlier period, most likely with stone foundation, mud wall and terrazzo-floor. The 1st period inner tower had two floor levels above the fill of the earth-timber period ditch. Drains similar to the drain of the via sagularis uncovered in trenches II and IV were found in several Pannonian auxiliary forts (e. g. at Matrica and Carnuntum) ${ }^{64}$

The excavation of the angle tower is important in terms of the dating of fan shaped towers. Earlier I suggested that the fan shaped towers of Matrica and Campona can be dated to the last years of Constantine's reign. ${ }^{65}$ This tower type was most certainly built at a later date at Intercisa. ${ }^{66}$ Our excavations yielded dating evidence from Annamatia. In the fill of the stone-period ditch a coin of Constantius II was found which can be dated to between 337-341. The fan shaped towers of Baracs were built after this date. The tower had three inner clayey floor levels, indicating that the fort was used for a long time after the building of the tower. The robbed wall added to the northwestern wall of the gate tower proves that the northern gate was blocked by an $\mathrm{U}$ shaped tower. The unusual solution is that the longitudinal wall of the tower was added to the northwestern corner of the earlier one. A similar addition was observed in the auxiliary fort at Leányvár. ${ }^{67}$ Its only function was probably that the earlier towers had relatively small dimensions $(2.5 \mathrm{~m})$. Another possibility would be that the gate towers of Baracs would have had an Ulcisia Castra-type addition, but at Szentendre the porta praetoria had this tower type ${ }^{68}$ A similarly wide foundation ditch was observed at Leányvár. ${ }^{69}$ Late Roman stamped bricks (Terentius dux-, ...

${ }^{61}$ StIGLITZ, H.: Das Auxiliarkastell Carnuntum 2. Forschungen 1977-1988. ÖAI Sonderschriften 29. Wien 1997, 69, KANDLER, M.-VetTERS, H.: Der römische Limes in Österreich. Ein Führer. Wien 1989, 182.

${ }^{62}$ Póczy, K.: Közmüvek a római kori Magyarországon - Kommunalwerke der Römerzeit in Ungarn. Budapest 1980, 79-84; PETRIKOVITS, H. VON: Die Innenbauten römischer Legionslager während der Prinzipatszeit. Opladen 1975, 106.

${ }^{63}$ GABLER, op. cit. (note 15), 50-53.

${ }^{64}$ KovÁCS, op. cit. (note 60), 44; KANDLER, M.: Das Auxiliarkastell Carnuntum. 2. Forschungen seit 1989. ÖAI Sonderschriften 30. Wien 1997, 52-56.

${ }^{65}$ KovÁCS, op. cit. (note 60), 49-54.

${ }^{66}$ LÖRINCZ, B.-VISY, Zs.: Die Baugeschichte des Auxiliarkastells von Intercisa. Roman Frontier Studies 1979. BAR IS 72, Oxford 1980, 691-692.

${ }^{67}$ KuZMOVÁ, K.-RAJTÁR, J.: Bisherige Erkenntnisse zur Befestigung des Römerkastells in Iža. SlovArch 34, 1986, 192-204, Abb. 4.

${ }^{68}$ NAGY, T.: A Fővárosi Régészeti és Ásatási Intézet jelentése az 1938-1942. évek között végzett kutatásokról - Report of the Municipal Institute for Archaeology and Excavations on the investigations conducted between 1938-1942. BudRég 13, 1943, 393-394; Der römische Limes in Ungarn. Székesfehérvár 1976, 77.

${ }^{69}$ Ibid., 207, Abb. 15, Nr. 2. 
dux-, Quadriburgium-type: Cat. Nos. 7, 9-10, 15) prove that the towers were used in the Valentinian period as well. ${ }^{70}$ This is hardly surprising; knowing that the region was poor, the Roman brick material was also reused and carried away.

It is noteworthy that the finds that can be associated with women (golden earring, bracelets bone and glass beads, glass cameo) confirm our earlier hypothesis about the abandonment of the auxiliary vici and the settlement of the civilian population in the fort in the 4th century. ${ }^{71}$ It is important to note that the finds from the inner building predate the hypothetical time of the abandonment of the vici (middle of the 4th century). This would suggest that this move could happen earlier as well (after 260 or during the tetrarchy). ${ }^{22}$ The last period of the building can be dated to before the mid-4th century on the basis of the coins of Constantius II (Cat. Nos 5-8). The timber building found in trench I belongs to the last period of the fort. We have no data about the Hun period of the fort, but Langobard finds from this area indicate the further use of the earlier Roman castellum. ${ }^{73}$

Pázmány Péter Catholic University

H-2081 Piliscsaba

${ }^{70}$ For their dating cp., LŐRINCZ, B.: A későrómai hídföállások bélyeges téglái Valeriában - Die Ziegelstempel der spätrömischen Brückenkopffestungen in der Provinz Valeria. Pannoniai kutatások. A Soproni Sándor emlékkonferencia elöadásai. Bölcske, 1998 október 7. Szekszárd 1999, 53-68; LÖRINCZ, B.: Pannonische Ziegelstempel II. Limes-Strecke Vetus Salina-Intercisa. DissArch II, 7. Budapest $1978,42$.

${ }^{71}$ Kovács, op. cit. (note 60), 123-131, 166-169.

${ }^{72} \mathrm{Cf}$. the destruction in the auxiliary vicus of Intercisa: VISY, Zs.: Intercisa. A római kori Dunaújváros. Budapest 1977, 32-39; Dunaújváros története. Dunaújváros 2000, 50-52, 55-56.

${ }^{73}$ Ibid., 75. 